\title{
Seasonal movements and behaviour of basking sharks from archival tagging: no evidence of winter hibernation
}

\author{
David W. Sims ${ }^{1, *}$, Emily J. Southall ${ }^{1}$, Anthony J. Richardson ${ }^{2}$, Philip C. Reid ${ }^{2}$, \\ Julian D. Metcalfe ${ }^{3}$ \\ ${ }^{1}$ Marine Biological Association, and ${ }^{2}$ Sir Alister Hardy Foundation for Ocean Science, The Laboratory, Citadel Hill, \\ Plymouth PL1 2PB, United Kingdom \\ ${ }^{3}$ Centre for Environment, Fisheries and Aquaculture Science, Lowestoft Laboratory, Lowestoft NR33 0HT, United Kingdom
}

\begin{abstract}
Habitat selection processes in highly migratory animals such as sharks and whales are important to understand because they influence patterns of distribution, availability and therefore catch rates. However, spatial strategies remain poorly understood over seasonal scales in most species, including, most notably, the plankton-feeding basking shark Cetorhinus maximus. It was proposed nearly $50 \mathrm{yr}$ ago that this globally distributed species migrates from coastal summerfeeding areas of the northeast Atlantic to hibernate during winter in deep water on the bottom of continental-shelf slopes. This view has perpetuated in the literature even though the 'hibernation theory' has not been tested directly. We have now tracked basking sharks for the first time over seasonal scales (1.7 to $6.5 \mathrm{mo}$ ) using 'pop-up' satellite archival transmitters. We show that they do not hibernate during winter but instead undertake extensive horizontal (up to $3400 \mathrm{~km}$ ) and vertical (>750 m depth) movements to utilise productive continental-shelf and shelf-edge habitats during summer, autumn and winter. They travel long distances (390 to $460 \mathrm{~km}$ ) to locate temporally discrete productivity 'hotspots' at shelf-break fronts, but at no time were prolonged movements into open-ocean regions away from shelf waters observed. Basking sharks have a very broad vertical diving range and can dive beyond the known range of planktivorous whales. Our study suggests this species can exploit shelf and slope-associated zooplankton communities in mesopelagic (200 to $1000 \mathrm{~m})$ as well as epipelagic habitat ( 0 to $200 \mathrm{~m}$ ).
\end{abstract}

KEY WORDS: Shark $\cdot$ Strategy $\cdot$ Satellite archival telemetry $\cdot$ Oceanographic fronts

\section{INTRODUCTION}

Only 3 of the approximately 500 species of shark obtain food by filtering zooplankton, but these are among the largest sharks, and of all marine vertebrates only whales are larger. In contrast to baleen whales, however, the habitat of planktivorous sharks is largely unknown because tracking their movements and behaviour is comparatively difficult (Nelson et al. 1997, Eckert \& Stewart 2001). This is despite an urgent need for more information because, for example, the second largest fish species, the basking shark Cetorhinus

*Email: dws@mba.ac.uk maximus, is classified as endangered in the northeast Atlantic as a result of at least 2 centuries of exploitation (Hilton-Taylor 2000). Although basking sharks apparently grow slowly (Parker \& Stott 1965), have a late age at maturity (Matthews 1950), and a low reproductive rate (Sund 1943), a lack of knowledge about movements and habitat requirements continues to hinder appropriate conservation assessment of this species. Until now, only 1 short-term tracking of an individual has been possible (Priede 1984).

During summer months in boreal to warm-temperate waters of the Atlantic Ocean, basking sharks filter- 
feed on near-shore zooplankton (Sims \& Quayle 1998), but beyond these brief glimpses their whereabouts for much of the year remains a mystery. It has long been thought that basking sharks migrate from summer feeding grounds to deep-water for winter hibernation because they are absent from surface waters at this time, and apparently shed their gill-raker filtering apparatus (Parker \& Boeseman 1954). To counter this potential energy loss from swimming without the possibility of gainful feeding, it was proposed they hibernate on the seabed until spring when zooplankton densities increase (Parker \& Boeseman 1954, Matthews 1962). However, a recent study showed basking sharks feed profitably at much lower threshold densities of zooplankton than previously thought, suggesting hibernation to be unnecessary (Sims 1999).

To test these ideas directly, and to determine for the first time the seasonal movements and habitat of basking sharks, we attached 'pop-up' satellite archival transmitters to individuals as they foraged during summer off the UK coast. In addition to providing the first information on the movements and behaviour of basking sharks over seasonal scales, we combine satellitearchival telemetry with remote sensing of ocean colour and continuous plankton recorder survey data to investigate whether movements are related to areas of enhanced secondary productivity.

\section{MATERIALS AND METHODS}

Study areas. Basking sharks were located in 2 study areas. An area in the English Channel off Plymouth $\left(50^{\circ} 20^{\prime}-50^{\circ} 10^{\prime} \mathrm{N}, 003^{\circ} 57^{\prime}-004^{\circ} 20^{\prime} \mathrm{W}\right)$ was investigated during May 2001, and an area comprising Lower Loch Fyne and the northern Clyde Sea, Scotland $\left(56^{\circ} 00^{\prime}-55^{\circ} 35^{\prime} \mathrm{N}, 004^{\circ} 57^{\prime}-005^{\circ} 28^{\prime} \mathrm{W}\right)$ was investigated in July 2001.

Fish tagging. To track basking sharks we used 'popup' archival transmitting (PAT) tags (length: $175 \mathrm{~mm}$; mass in air: $76 \mathrm{~g}$ ). These tags combine a data-logger that records swimming depth, water temperature and light level with an Argos-certified transmitter with $0.5 \mathrm{~W}$ power output (Wildlife Computers). Depth is measured to $1000 \mathrm{~m}$ (min. resolution: $0.5 \mathrm{~m}$ ), temperature from -40 to $60^{\circ} \mathrm{C}$ (min. resolution, $0.05^{\circ} \mathrm{C}$ ), and light level is measured as irradiance $\left(\mathrm{W} \mathrm{cm}^{-2}\right)$ at $550 \mathrm{~nm}$ wavelength. These parameters are sampled each minute and stored as summary data over set intervals of 4 or $6 \mathrm{~h}$ (time-at-depth and time-attemperature histograms; temperature-depth profiles; maximal change in light intensity over time). PAT tags were fitted with a 1.8-m long monofilament tether connected to a $40-\mathrm{mm}$ long stainless steel T-bar arrowhead via wire tracer. Using a $10 \mathrm{~m}$ research vessel, we approached surface-feeding sharks slowly from behind at a lateral distance of about $1 \mathrm{~m}$. When the vessel's bow drew level with the shark's first dorsal fin, the arrowhead was fastened rapidly $(<1 \mathrm{~s})$ through the middle of the fin using a rubber-band speargun pulled at approximately $40 \mathrm{~kg}$ pressure. Attached PAT tags trailed behind sharks close to the body, and the known distance from tag to the first dorsal fin $(1.8 \mathrm{~m})$ was used to obtain an estimate of total body length. After attachment, and at a preprogrammed time, each tag released itself from its host shark and floated to the surface where it was geolocated by Argos satellites (the 'popup' location) and data summaries transmitted.

Track reconstruction. The estimated accuracy of 'pop-up' locations of PAT tags determined by Argos receivers was between 350 and $1000 \mathrm{~m}$. Satelliteretrieved data of daily maximal rate of change in light intensity were used to estimate the local time of midnight or midday for longitude calculations (Hill 1994). The accuracy of these estimates is between \pm 0.15 and $1.20^{\circ}$ of longitude $\left(1^{\circ}\right.$ longitude $\left.=71.7 \mathrm{~km}\right)($ Welch \& Eveson 1999, Block et al. 2001). Only consecutive longitude estimates $<3^{\circ}$ apart were used for geolocation. Longitude estimates were discarded for days when the maximal light-intensity change was dive-induced, i.e. measured at times inconsistent with the regionally expected times of dawn or dusk. Latitude was fixed using summary data. Daily temperature-depth (TD) profiles from sharks, or histogram summaries of swimming depth and water temperature, were used to determine minimum and maximum sea surface temperature (SST) on each day for which longitude was estimated. We then used nighttime advanced very high resolution radiometer (AVHRR) remote-sensing images of SST to fix latitude along the longitude. A java applet viewer (JAV) was used to determine SST values for individual pixels on each false-colour image. Colour intensity in each pixel (representing a $1 \times 1 \mathrm{~km}$ area) was coded by a number from 0 to 256 . By scanning each image using the JAV's cursor, the latitude representing the best fit of temperature-scaled colour criteria to measured SST values was made along each longitude estimate. Colour-criteria number values were converted to ${ }^{\circ} \mathrm{C}$ using a calibrated scale on each image. If cloud cover was high on a particular day, remote sensing SST images on the next closest day (before or after) were used to fix latitude. Only images to a maximum of $5 \mathrm{~d}$ before or after were used. The latitude estimate, fixed using SST, was then filtered for water-mass type, depth and swim-speed anomalies. TD profiles were used to determine water-mass type (stratified, frontal, mixed). If the water mass at the shark's location from SST images was inconsistent with that determined from TD profiles, then further JAV scans on the next available image were conducted. 
Similarly, if the maximum daily depth attained by each shark was greater than the known depth at the estimated location shown on oceanographic charts, and/or the distance between consecutive geolocations was greater than $100 \mathrm{~km} \mathrm{~d}^{-1}$ straight-line travel speed (1.4 ${ }^{\circ}$ longitude; Sims 2000), then the geolocation was considered anomalous and further JAV scans were initiated. If a shark's position could not be resolved using other daily SST images, then the longitude estimate was discarded from the dataset.

The accuracy of latitude-position estimates varied over the range of standard deviation per location of 0.01 to $1.56^{\circ}$ latitude (1.11 to $173.52 \mathrm{~km}$; $\mathrm{n}=31$ locations examined), which were similar error fields to those associated with longitude estimation (Welch \& Eveson 1999, Block et al. 2001).

Plankton analysis. The surface chl a pigment concentration at each geolocation of Shark 1 was determined for a 6 mo period (1 April to 30 September 2001) using daily SeaWiFS (nasa_chlor_a) remote sensing images. As with SST determinations, a JAV was used to obtain precise number values corresponding to map-colour criteria, which were converted to chl a concentrations using the formula:

$$
C=10^{\left[(\mathrm{n} \times 0.015)+\log _{10}(0.01)\right]}
$$

where $C$ is chl a concentration in $\mathrm{mg} \mathrm{m}^{-3}$ and $\mathrm{n}$ is pixel colour-criteria number. At each geolocation, 13 determinations were made: 1 at the estimated location of the shark and 3 others at $0.2^{\circ}$ intervals in each of 4 compass directions (north, east, south, west) originating at the shark's estimated location.

To estimate the long-term monthly chlorophyll and copepod abundance for the Goban Spur region $\left(48.0-50.0^{\circ} \mathrm{N}, 10.5-12.5^{\circ} \mathrm{W}\right)$ we used data from the continuous plankton recorder (CPR) survey. This plankton sampler, which is towed behind merchant ships on their normal routes at about $7 \mathrm{~m}$ depth, filters plankton from the water on a constantly moving band of silk of $270 \mu \mathrm{m}$ mesh. Samples equivalent to 10 nautical miles $(18.5 \mathrm{~km})$ of tow and approximately $3 \mathrm{~m}^{3}$ of water filtered are analysed under a microscope using a standard procedure (Warner \& Hays 1994). To estimate chlorophyll, we used phytoplankton colour, a visual index of the intensity of greenness observed on the silk, and for total copepod abundance, we summed all the counts for all species found (developmental stages: copepodites, $\mathrm{CI}$ to $\mathrm{CV}_{\text {; }}$ adults, CVI). Data were from 1955 to 2000 and comprised 1094 samples.

\section{RESULTS}

'Pop-up' locations and behavioural data were obtained for 5 basking sharks, totalling 686 d tracking time between May 2001 and January 2002 (Table 1). These data provide unique insights into their summer movements and over-wintering behaviour.

\section{Summer movements}

Shark 1, a $4.5 \mathrm{~m}$ long female, travelled a minimum distance of $1878 \mathrm{~km}$ in $77 \mathrm{~d}$ (24 May to 8 August) (Table 1). From the tagging area off Plymouth it moved west and then northward before the PAT tag released and was geolocated by satellites, just south of the Hebrides in Scotland (Fig. 1A). The track reconstruction for this individual showed that in early June, within 7 to $10 \mathrm{~d}$ of being tagged, Shark 1 was near the productive Ushant tidal front off Brittany (B), France (Fig. 1A). Daily vertical temperature profiles confirmed the frontal habitat. This shark spent between 49 (night) and $71 \%$ (day) of the time in the uppermost $10 \mathrm{~m}$ of water, although short-term dives to between 90 and $120 \mathrm{~m}$ depth did occur, though mainly at night (Fig. 2A). Some 11 d later, this shark was geolocated $460 \mathrm{~km}$ west, on the shelf edge (Goban Spur region), where it remained for at least $8 \mathrm{~d}$ (Fig. 1A,C). Near the shelf edge, Shark 1 spent progressively less time in the uppermost $10 \mathrm{~m}$ during the day (39 decreasing to $12 \%)$, whilst more time was spent at depths below $90 \mathrm{~m}$ (Fig. 2B,C). The temporal change in maximum daily dive depth shows that Shark 1 undertook frequent dives through the water column from shallow $20 \mathrm{~m}$ depths to $100 \mathrm{~m}$ depths, dives which then in-

Table 1. Cetorhinus maximus. Summary of tracking data for basking sharks

\begin{tabular}{|lccccccccrrr|}
\hline $\begin{array}{c}\text { Shark } \\
\begin{array}{c}\text { Estimated } \\
\text { total body } \\
\text { length }(\mathrm{m})\end{array}\end{array}$ & Sex & $\begin{array}{c}\text { Date } \\
\text { tagged } \\
(\mathrm{dd} / \mathrm{mm} / \mathrm{yy})\end{array}$ & $\begin{array}{c}\text { Latitude } \\
\text { tagged } \\
\left({ }^{\circ} \mathrm{N}\right)\end{array}$ & $\begin{array}{c}\text { Longitude } \\
\text { tagged } \\
\left({ }^{\circ} \mathrm{W}\right)\end{array}$ & $\begin{array}{c}\text { 'Pop-up' } \\
\text { date }\end{array}$ & $\begin{array}{c}\text { Latitude } \\
\text { 'pop-up' } \\
\left({ }^{\circ} \mathrm{N}\right)\end{array}$ & $\begin{array}{c}\text { Longitude } \\
\text { 'pop-up' } \\
\left({ }^{\circ} \mathrm{W}\right)\end{array}$ & $\begin{array}{c}\text { No. of } \\
\text { track } \\
\text { days }\end{array}$ & $\begin{array}{c}\text { No. of } \\
\text { loca- } \\
\text { tions }\end{array}$ & $\begin{array}{c}\text { Min. distance } \\
\text { moved between } \\
\text { locations }(\mathrm{km})\end{array}$ \\
\hline 1 & 4.5 & $\mathrm{~F}$ & $24 / 05 / 01$ & 50.39 & 4.11 & $07 / 08 / 01$ & 56.42 & 7.26 & 77 & 10 & 1878 \\
2 & 6.0 & - & $25 / 05 / 01$ & 50.32 & 4.13 & $07 / 12 / 01$ & 49.87 & 2.42 & 197 & 8 & 1616 \\
3 & 6.5 & - & $31 / 07 / 01$ & 55.87 & 5.39 & $20 / 09 / 01$ & 55.59 & 5.12 & 52 & 2 & 39 \\
4 & 7.0 & $\mathrm{~F}$ & $28 / 07 / 01$ & 55.87 & 5.39 & $05 / 01 / 02$ & 50.79 & 5.35 & 162 & 26 & 3421 \\
5 & 5.5 & $\mathrm{~F}$ & $24 / 05 / 01$ & 50.29 & 4.11 & $07 / 12 / 01$ & 52.28 & $1.81{ }^{\circ} \mathrm{E}$ & 198 & 3 & 581 \\
\hline
\end{tabular}



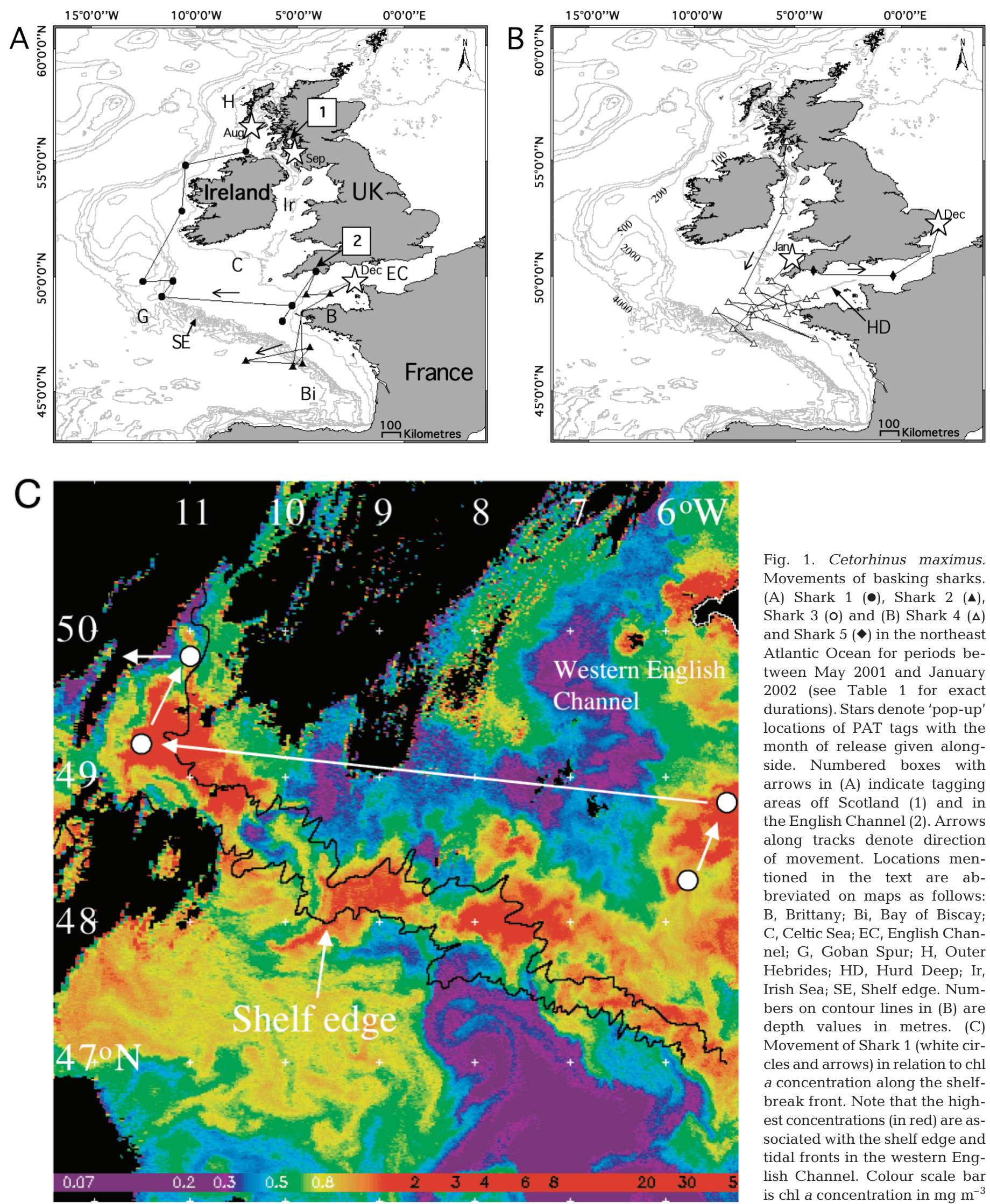

Fig. 1. Cetorhinus maximus. Movements of basking sharks. (A) Shark 1 (•), Shark $2(\mathbf{\Delta})$, Shark 3 (0) and (B) Shark $4(\Delta)$ and Shark $5(\diamond)$ in the northeast Atlantic Ocean for periods between May 2001 and January 2002 (see Table 1 for exact durations). Stars denote 'pop-up' locations of PAT tags with the month of release given alongside. Numbered boxes with arrows in (A) indicate tagging areas off Scotland (1) and in the English Channel (2). Arrows along tracks denote direction of movement. Locations mentioned in the text are abbreviated on maps as follows: B, Brittany; Bi, Bay of Biscay; C, Celtic Sea; EC, English Channel; G, Goban Spur; H, Outer Hebrides; HD, Hurd Deep; Ir, Irish Sea; SE, Shelf edge. Numbers on contour lines in (B) are depth values in metres. (C) Movement of Shark 1 (white circles and arrows) in relation to chl a concentration along the shelfbreak front. Note that the highest concentrations (in red) are associated with the shelf edge and tidal fronts in the western English Channel. Colour scale bar is chl a concentration in $\mathrm{mg} \mathrm{m}^{-3}$ 

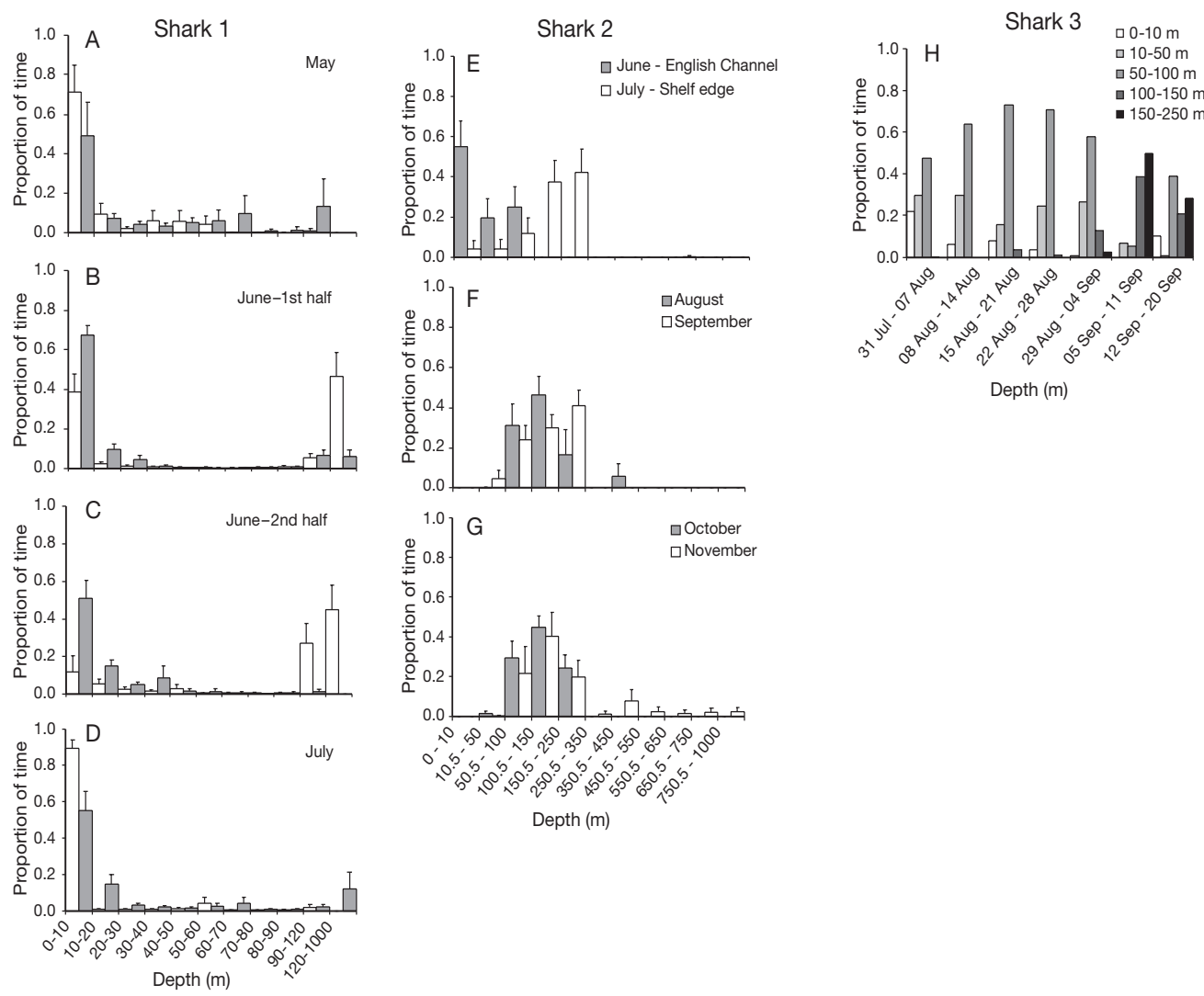

Fig. 2. Cetorhinus maximus. Depth preferences of Sharks 1 (A-D), 2 (E-G), $3(\mathrm{H})$ and 4 (I-L) over summer, autumn and winter in the northeast Atlantic. Columns in (A-D) represent depths preferred by Shark 1 during the day (white) and night (black). Columns and error bars on all panels denote the mean \pm 1 SEM
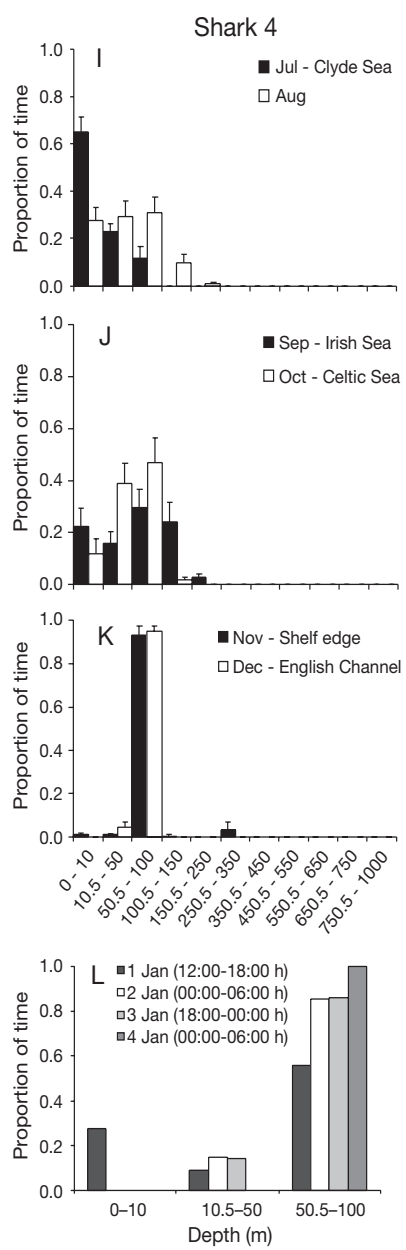

creased in maximum depth from 120 to $180 \mathrm{~m}$ when near the shelf edge (Fig. 3A). The temperature-depth profile indicates that this shark dived offshore in strongly stratified water masses with a vertical temperature range of approximately 9 to $15^{\circ} \mathrm{C}$ (Fig. 3A). When this shark moved into shallower shelf waters off western Scotland in July (Fig. 2D), a daytime shallowdiving pattern, similar to that seen in the English Channel in May and June, resumed.

In $197 \mathrm{~d}$ Shark 2 moved a minimum distance of $1616 \mathrm{~km}$ (Table 1). A similar summer behaviour pattern was shown by this $6 \mathrm{~m}$ long individual as seen for Shark 1, in that during May and June it spent time in the western English Channel near tidal fronts, before moving offshore in July to the shelf edge (Fig. 2B). This change in summer habitat from shelf to shelf edgefrontal regions also reflected a shift from surface feeding in June ( $75 \%$ of time spent in 0 to $50 \mathrm{~m}$ depth), to deeper vertical habitat selection during July and August on the shelf edge (modal time-at-depth: 100 to 150 and 150 to $250 \mathrm{~m}$ ). There were also occasional dives to between 350 and $650 \mathrm{~m}$ depth (Fig. 2E,F). This shark occupied shelf-edge habitat in the Bay of Biscay
(Fig. 1A) which was further south than areas selected by Shark 1. The Biscay region was characterised by warmer surface waters $\left(16\right.$ to $\left.17^{\circ} \mathrm{C}\right)$, although the shark continued to undertake frequent deep dives into cooler water $\left(10\right.$ to $\left.13^{\circ} \mathrm{C}\right)$ (Fig. 3D).

This general pattern of deep diving when verticalhabitat extent increased was supported by Sharks 3 and 4. Although they remained in the deep, fjord-like Clyde Sea for 1 to 2 mo during summer, they made very frequent, sometimes daily dives from the surface to 80 to $160 \mathrm{~m}$ and back again (Figs. 2H,I,J \& 3B,C). These sharks occupied stratified and frontal water masses in summer, and during dives experienced a temperature change of between 8 and $16^{\circ} \mathrm{C}$ (Fig. 3B,C). In mid-September, Shark 3 dived to between 160 and $185 \mathrm{~m}$, where it remained for $6 \mathrm{~d}$ before surfacing (Figs. 2H \& 3B).

\section{Shelf-edge movements}

Basking sharks utilised not only inshore tidal fronts for summer foraging, but also shelf-edge areas (loca- 

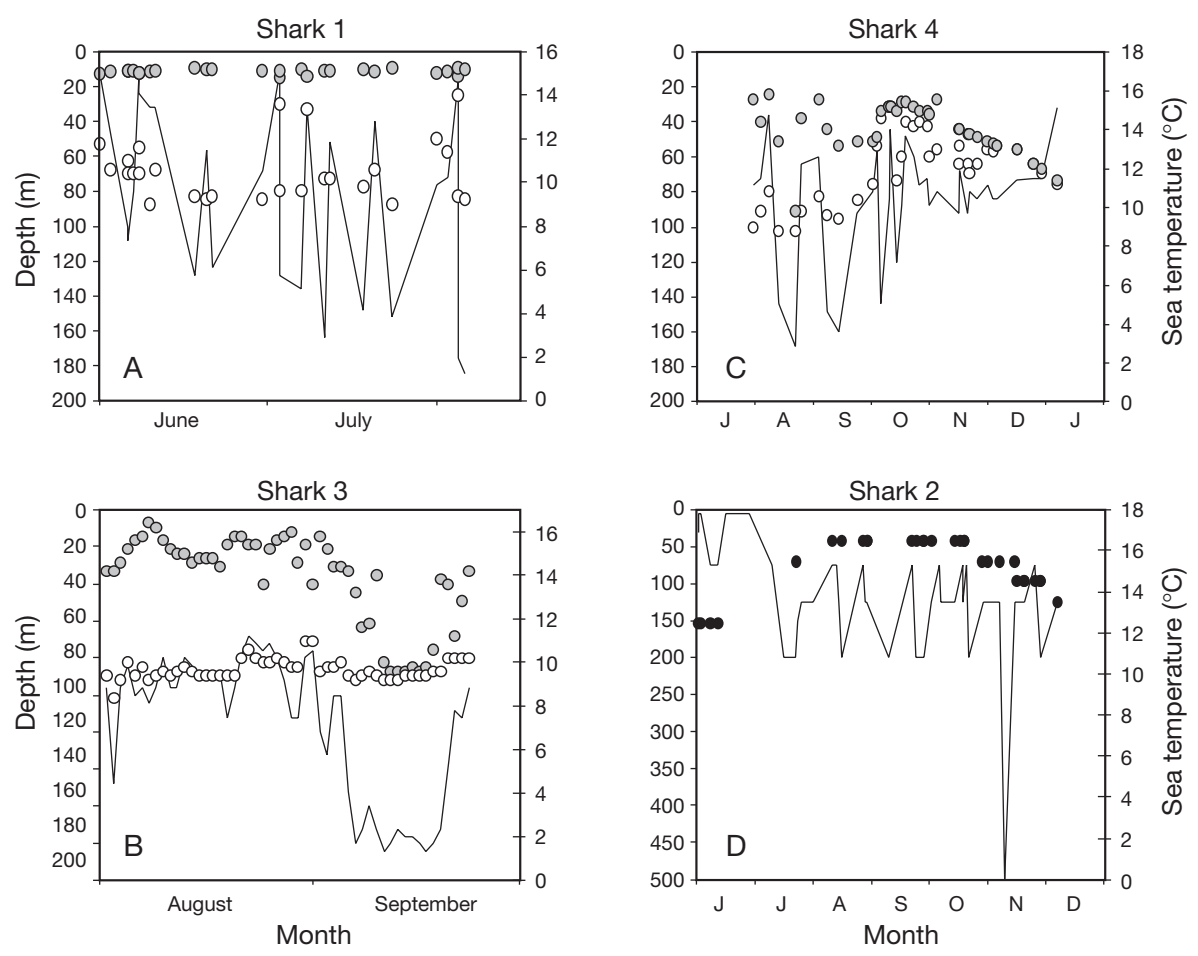

Fig. 3. Cetorhinus maximus. Temperature and depth profiles of basking sharks tracked in the northeast Atlantic. (A-C) Maximum daily dive depth (black line) and minimum (open circle) and maximum (shaded circle) daily temperature; (D) midpoint depth in each daily modal-depth class (black line) and the midpoint temperature in each daily modaltemperature class (filled circle)

tions $>200 \mathrm{~m}$ deep). To determine, for the first time, the relationship between broad-scale plankton abundance and foraging movements of basking sharks, we investigated trends in surface primary production (chl a pigment concentration) at each position of Shark 1 over a 6 mo period (1 April to 30 September 2001) using SeaWiFS remote-sensing images (e.g. Fig. 1C). The shelfedge positions occupied by Shark 1 on 14 and 17 June coincided with the highest levels of surface primary production seen at these locations for 6 mo (between 2 and $67 \mathrm{mg} \mathrm{m}^{-3}$ compared to a background level of $<1 \mathrm{mg} \mathrm{m}^{-3}$ ), and higher than those encountered previously off France (Fig. 4A). A SeaWiFS chl a image from 19 June 2001 indicates that in mid-June Shark 1 was associated with a discrete productivity 'hotspot' over the shelf edge (Fig. 1C). By contrast, prior to this shark moving north on or after 22 June, the level of primary production around its position had declined to about $0.5 \mathrm{mg} \mathrm{m}^{-3}$ (Fig. 4A).

Patterns of phytoplankton and total copepod abundances measured by the CPR survey over the same area show high congruence (Fig. 4B), indicating that peaks in primary and secondary production in this region are tightly coupled temporally. Basking Shark 1 arrived in the Goban Spur region at a time when total copepod abundance peaked (Fig. 4B). Decreased numbers of copepods in July at the Goban Spur coincided with the relatively fast northward movement of Shark 1 into areas where copepod abundance peaked in August (CPR data not shown).

\section{Autumn-winter behaviour}

In addition to summer foraging movements, 3 basking sharks were tracked across seasonal scales (May to December and July to January) (Sharks 2, 4, 5; Table 1). In December and January these individuals were located by satellites in shelf waters off southern England (Fig. 1A,B). Basking sharks in the Clyde Sea showed limited horizontal movements during summer foraging, but Shark 4 moved south during September, indicating residence in the Clyde Sea was a transitory behaviour. This shark, a $7 \mathrm{~m}$ long female, left the Clyde Sea in mid-September (temperature range: 11.0 to $14.0^{\circ} \mathrm{C}$ ) and moved south through the Irish Sea over the next month before arriving in the southern Celtic Sea near the shelf edge in mid-October (temperature range: 14.0 to $16.0^{\circ} \mathrm{C}$ ). From mid-October 2001 to early January 2002 this shark remained off south-west England, undertaking ranging movements to the shelf edge and into the western English Channel near a deep, narrow trench known as the Hurd Deep (Fig. 1B). In November and December this female spent 80 to $90 \%$ of its time between 50 and $100 \mathrm{~m}$ depth, although it occasionally went shallower and dived from the surface to between 250 and $350 \mathrm{~m}$ depth (Fig. 2K). Large-amplitude vertical movements in winter were less frequent than during summer because the maximum dive depth became progressively shallower ( 90 to $50 \mathrm{~m})$, concomitant with movements into inshore areas with a fairly constant temperature of approximately $11^{\circ} \mathrm{C}$ (Fig. 3C). 

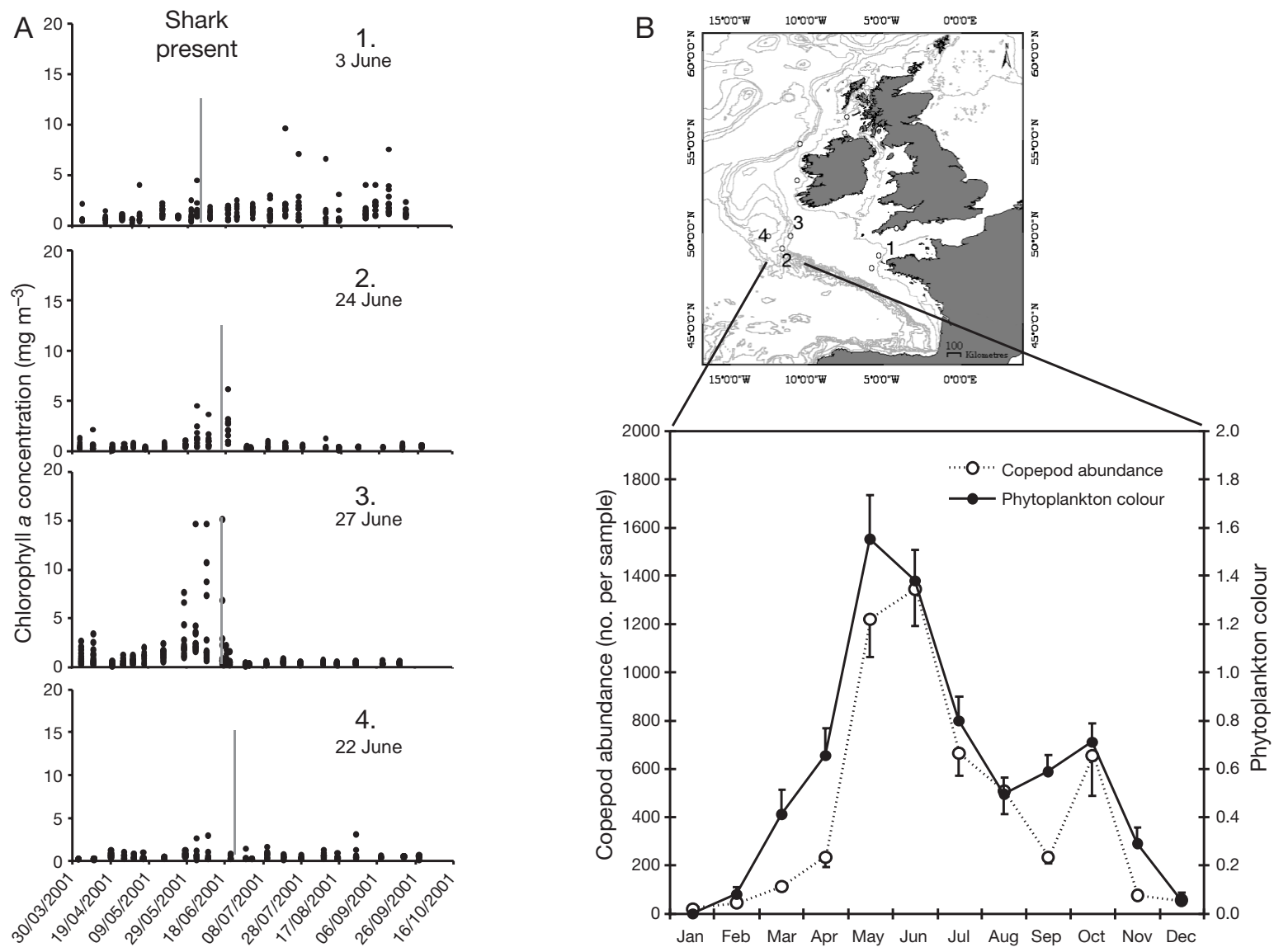

Fig. 4. Cetorhinus maximus. Trends in chl a pigment concentration at (A) 4 positions occupied by Shark 1 between 3 and 22 June (Panels 1-4) determined from SeaWiFS satellite images. The 6 mo period in each panel extends from 1 April to 30 September 2001. Grey vertical lines denote the time when Shark 1 was present at each location during the 6 mo period. Two high chl a values (41 and $67 \mathrm{mg} \mathrm{m}^{-3}$ ) that occurred immediately prior to the shark's presence at that location were omitted from Panel 3 for clarity. (B) Mean monthly phytoplankton colour and total copepods measured by the CPR survey in the Goban Spur region (shown on inset map) between 1955 and 2000. Numbered locations on inset map (1-4) refer to positions examined for phytoplankton concentrations in Panels 1-4 in (A). Error bars on mean monthly values denote 1 SEM. Arrow denotes time when Shark 1 was present in the Goban Spur region

Movements of Sharks 2 and 5 were similarly broad during winter. Shark 5, a $5.5 \mathrm{~m}$ long immature female, remained within the English Channel from summer to winter occupying water of about $17.0^{\circ} \mathrm{C}$ in October, before moving into the southern North Sea (Fig. 1B). By contrast, from mid-October to mid-November Shark 2 was geolocated on the shelf edge in the Bay of Biscay where it had possibly remained since the summer. It moved through the water column between 10 and $250 \mathrm{~m}$ on a regular basis, with some dives to between 350 and $450 \mathrm{~m}$ (Fig. 2F). One dive in November extended from the surface to between 750 and $1000 \mathrm{~m}$ depth at the mesopelagic-bathypelagic boundary, where the shark stayed for nearly an hour (Fig. 2G). Between 17 November and 7 December this shark moved back into the western English Channel and conducted similar deep-diving behaviour in the Hurd Deep (maximum dive depth: $176 \mathrm{~m}$ ). At fine time- scales we also found this shark was active during $6 \mathrm{~h}$ time periods on consecutive days in early December, ranging between 50 and $250 \mathrm{~m}$ depth. Similarly, in early January 2002, Shark 4 also showed vertical movements on consecutive days ranging from between 0-10 and 50-100 m (Fig. 2L). However, even though basking sharks were active during winter, they generally spent less time near the surface compared to depths preferred in summer months (Fig. 2G,K,L).

\section{DISCUSSION}

Over fine- to meso-horizontal scales ( $\mathrm{m}$ to $10 \mathrm{~s} \mathrm{~km}$ ) in the western English Channel, basking sharks exhibit selective foraging behaviour in the richest zooplankton patches, and move between patches along tidal fronts over periods of 1 to $2 \mathrm{~d}$ (Sims \& Quayle 1998). How- 
ever, nothing is known of broad-scale seasonal movements in response to production associated with largescale oceanographic features.

The seasonal movements of basking sharks in this study were generally over long distances, but routes were exclusively associated with the continental shelf. Extended movements into open-ocean regions away from north-east Atlantic shelf and shelf-edge waters were not observed. A unifying feature of the movements, however, was that they resulted in the occupation of habitats with enhanced productivity in both inshore (English Channel and Clyde Sea) and offshore shelf-edge areas (Pingree et al. 1975, Adams 1986, Le Fevre 1986). The continental shelf-edge area where Sharks 1 and 2 spent between 1 and 4 mo respectively, is a frontal region of high relative phyto- and zooplankton abundance (Le Fevre 1986). We found that Shark 1 travelled west for about $500 \mathrm{~km}$ to the shelfedge, and located and remained within a productivity 'hotspot' for about $1 \mathrm{wk}$. Whilst we do not know whether this individual was actively feeding, it seems likely this movement was related to foraging given that basking sharks are known to feed from at least May until August (Sims \& Merrett 1997, Sims et al. 1997). Our study suggests that as well as foraging within and between prey patches over fine- to meso-scales (Sims \& Quayle 1998), basking sharks probably locate and remain within temporally discrete productivity 'hotspots' occurring seasonally along large-scale frontal features at much greater spatial scales (100s to 1000s of $\mathrm{km})$. The physiological and behavioural mechanisms used by this species to orientate to distant locations is unknown, but could involve active orientation to geophysical directional clues, such as the earth's magnetic field (Metcalfe et al. 1993), or thermoreception (Sand 1938, Crawshaw \& Hammel 1973) of sharp changes in water temperature that is characteristic of frontal systems.

The consistent pattern of vertical movements of basking sharks through the water column in both shelf and shelf-edge habitat probably represents preysearching behaviour. Short-term trackings of whale sharks Rhincodon typus showed frequent dives from the surface to near bottom (50 to $80 \mathrm{~m}$ ) and back again when foraging along a reef edge (Gunn et al. 1999). Hence, dives by this plankton-feeding shark as well as in basking sharks may function in the location of discrete layers of prey (Josse et al. 1998) and possibly olfactory trails (Carey \& Scharold 1990). Olfactory and gustatory stimuli useful for locating food or identifying particular water masses will be distributed more extensively in the horizontal plane than vertically, due to current shear between horizontal water layers of differing density (Carey \& Scharold 1990, Klimley et al. 2002). Thus, deep diving probably facilitates sampling of a large number of water-mass layers for chemical clues over a short time period. Frequent deep dives have also been documented for pelagic predatory sharks (e.g. blue and great white sharks) (Carey \& Scharold 1990, Boustany et al. 2002), and teleosts such as blue marlin and bluefin tuna (Block et al. 1992, 2001), indicating this behaviour is probably a ubiquitous search strategy for both epipelagic planktivores and macropredators.

However, basking sharks in the Clyde Sea and in shelf-edge habitat also spent more time during the day at deep depths compared to nighttime when they were generally within 10 to $50 \mathrm{~m}$ of the surface. This diel change in preferred depth of basking sharks is consistent with a response to diel vertically migrating zooplankton, which also occupy deeper depth strata during the day before rising to near the surface at night (e.g. Hays et al. 1995). Basking sharks, therefore, probably prospect for zooplankton by utilising deep dives irregularly, but also show predictable vertical movements presumably when feeding in thick swarms of diel migrating zooplankton.

The basking sharks tracked in this study utilised a very broad vertical habitat (0 to 750-1000 m depth), extending from the surface across both epipelagic and mesopelagic zones over a time scale of hours. Together with their long-distance movements, this indicates that survival on patchily distributed zooplankton by largebodied animals requires both extensive horizontal and vertical movements. Broad-scale movements of baleen whales also reflect this apparent necessity, but maximum dive depths recorded for these species range from 170 to $470 \mathrm{~m}$ (Schreer \& Kovacs 1997, Panigada et al. 1999). Therefore, by diving deeper and without the need to surface for air, basking sharks may gain a significant advantage over mammalian competitors (notably mysticete whales) by exploiting deep-water zooplankton communities beyond their range. This suggests a revised niche for basking sharks, and perhaps other plankton-feeding elasmobranchs (e.g. whale sharks, mobulid rays), as fish capable of exploiting resources throughout the epipelagic and mesopelagic realms.

It was hypothesised about 50 yr ago that basking sharks hibernate during winter in deep water off the continental slope (Parker \& Boeseman 1954, Matthews 1962). We showed from PAT tag release locations in December and January that basking sharks were located in continental shelf areas, often close to the coast. Their horizontal habitat selection in summer, autumn and winter was broadly similar. Furthermore, they exhibited diving activity and long-range movements during winter indicating they do not remain motionless on the seabed to conserve energy when seasonal zooplankton levels decline, as suggested in previous studies (Parker \& Boeseman 1954, Matthews 
1962). Taken together, our data show that basking sharks do not hibernate. Instead, we show that the continental shelf and shelf edges are winter habitats for this species in the northeast Atlantic. Basking sharks have also been caught in trawls during winter off shelf edges in New Zealand (Francis \& Duffy 2002), indicating that this habitat type may be globally important for this species. Although we can now reject the longstanding 'hibernation' theory as an explanation of the seasonal disappearance of basking sharks, we did find that they spent less time near the surface during winter than in summer. This seasonal decrease in basking behaviour means they are much less likely to be observed, which probably explains why for so long this species was thought to disappear into the depths during cold months.

The basking sharks in this study did not undertake prolonged movements into open-ocean regions away from productive shelf areas, which, coupled with evidence that approximately half the number of wintercaught specimens do not shed gill rakers (Parker \& Boeseman 1954), suggests some individuals probably feed in winter. The winter diving activity, as during summer, may serve to locate discrete layers of zooplankton prey. Energy-rich calanoid copepods such as Calanus finmarchicus and C. helgolandicus, the predominant prey of basking sharks, over-winter in shelf and shelf-edge deep water (100 to $2200 \mathrm{~m}$ ) (Hirche 1983, Williams \& Conway 1984, Heath et al. 2000) and so may be the targets of the very deep dives we measured. Non-migrating, deep-water copepods such as Euchaeta spp. (Mauchline 1995) could also be utilised by basking sharks at these depths.

Furthermore, it seems unlikely that basking sharks form local populations as was previously thought (Parker \& Stott 1965), because we found that sharks from the English Channel move to Scottish waters and vice versa over relatively short time periods (1 to $2 \mathrm{mo}$ ). Nevertheless, that fact that 1 basking shark tagged off Plymouth returned to the English Channel in winter, after spending most of the intervening time at the Bay of Biscay shelf edge, suggests some individuals may exhibit philopatry. This emphasises the importance of tidal and shelf-break frontal zones as foraging and over-wintering habitat for individual Cetorhinus maximus over annual cycles. In the northeast Atlantic this species is listed as endangered in the IUCN Red List of Threatened Species (Hilton-Taylor 2000). Current concerns about its conservation status as a result of suspected over-exploitation has led to statutory protection within UK territorial waters (up to $19 \mathrm{~km}$ from shore). Basking sharks in this study spent the majority of time outside the UK protected area, implying that if directed fisheries intensify in the future, this statutory measure will be ineffective.
A $5.5 \mathrm{~m}$ long female shark in this study, which was probably sexually immature (Matthews 1950), moved into the southern North Sea during winter. Basking sharks are known from this area in winter, although mature individuals have not been recorded (Van Diense \& Adriani 1953, Parker \& Boeseman 1954). Further tagging studies should focus on the movements of juveniles and sub-adults, because they may occupy areas where fishing activity is intense, increasing the likelihood of incidental capture in gear.

Finally, in free-ranging marine-animal behaviour studies, the abundance and availability of prey is rarely, if ever, assessed over the same spatial scales as predator movements (e.g. Weimerskirch et al. 1994). Hence, virtually nothing is known about search strategies and prey selection in relation to prey availability for highly mobile marine animals in the wild. In this study we related archival tracking of a basking shark to both remote-sensing images of ocean colour and CPR data. Although requiring further development, the initial results presented here identify the basking shark as a potential model species for testing hypotheses on free-ranging foraging strategies of a planktivorous fish over various spatio-temporal scales.

Acknowledgements. This research was funded by the UK Department for Environment, Food and Rural Affairs, the UK Natural Environment Research Council (NERC), the US National Geographic Society, The Royal Society and the Fisheries Society of the British Isles. The CPR survey is funded by the International Oceanographic Consortium, and agencies from Canada, The Faroes, France, Iceland, Ireland, Netherlands, Portugal, UK and USA. This research complied with all laws of the countries in which it was conducted. Satellite images were supplied by the NERC Satellite Receiving Station (SST images) and the NASA Goddard Flight Center (SeaWiFS images). We thank P. Miller and the NERC Remote Sensing and Data Analysis Service for image processing and advice, G. Arnold for discussions, and P. Harris, G. Hood, D. MacKenzie, S. Moszolics, A. Russell and D. Uren for assistance at sea. D.W.S. is supported by an NERC-funded MBA Research Fellowship.

\section{LITERATURE CITED}

Adams JA (1986) Zooplankton investigations in the Firth of Clyde. Proc R Soc Edinb B 90:239-254

Block BA, Booth DT, Carey FG (1992) Depth and temperature of the blue marlin, Makaira nigricans, observed by acoustic telemetry. Mar Biol 114:175-183

Block BA, Dewar H, Blackwell SB, Williams TD and 7 others (2001) Migratory movements, depth preferences, and thermal biology of Atlantic bluefin tuna. Science 293: $1310-1314$

Boustany AM, Davis SF, Pyle P, Anderson SD, Le Boeuf BJ, Block BA (2002) Satellite tagging: expanded niche for white sharks. Nature 415:35-36

Carey FG, Scharold JV (1990) Movements of blue sharks (Prionace glauca) in depth and course. Mar Biol 106: 329-342 
Crawshaw LI, Hammel HT (1973) Behavioural temperature regulation in the California horn shark, Heterodontus francisci. Brain Behav Evol 7:447-452

Eckert SA, Stewart BS (2001) Telemetry and satellite tracking of whale sharks, Rhincodon typus, in the Sea of Cortez, Mexico, and the north Pacific Ocean. Environ Biol Fish 60: 299-308

Francis MP, Duffy C (2002) Distribution, seasonal abundance and bycatch of basking sharks (Cetorhinus maximus) in New Zealand, with observations on their winter habitat. Mar Biol 140:831-842

Gunn JS, Stevens JD, Davis TLO, Norman BM (1999) Observations on the short-term movements and behaviour of whale sharks (Rhincodon typus) at Ningaloo Reef, Western Australia. Mar Biol 135:553-559

Hays GC, Warner AJ, Proctor CA (1995) Spatio-temporal patterns in the diel vertical migration of the copepod Metridia lucens in the northeast Atlantic derived from the Continuous Plankton Recorder survey. Limnol Oceanogr 40: $469-475$

Heath MR, Fraser JG, Gislason A, Hay SJ, Jonasdottir SH, Richardson K (2000) Winter distribution of Calanus finmarchicus in the northeast Atlantic. ICES J Mar Sci 57: 1628-1635

Hill RD (1994) Theory of geolocation by light levels. In: Le Boeuf BJ, Laws RM (eds) Elephant seals: population ecology, behaviour and physiology. University of California Press, Berkeley, p 227-236

Hilton-Taylor C (2000) IUCN red list of threatened species. International Union for the Conservation of Nature, Gland \& Cambridge

Hirche HJ (1983) Overwintering of Calanus finmarchicus and C. helgolandicus. Mar Ecol Prog Ser 11:281-290

Josse E, Bach P, Dagorn L (1998) Simultaneous observations of tuna movements and their prey by sonic tracking and acoustic surveys. Hydrobiologia 371/372:61-69

Klimley AP, Beavers SC, Curtis TH, Jorgensen SJ (2002) Movements and swimming behavior of 3 species of sharks in La Jolla Canyon, California. Environ Biol Fish 63:117-135

Le Fèvre J (1986) Aspects of the biology of frontal systems. Adv Mar Biol 23:163-299

Matthews LH (1950) Reproduction in the basking shark Cetorhinus maximus (Gunner). Phil Trans R Soc Lond B 234: 247-316

Matthews LH (1962) The shark that hibernates. New Sci 280: $756-759$

Mauchline J (1995) Bathymetric adaptations of life history patterns of congeneric species (Euchaeta: Calanoida) in a 2000 m water column. ICES J Mar Sci 52:511-516

Metcalfe JD, Holford BH, Arnold GP (1993) Orientation of plaice (Pleuronectes platessa) in the open sea: evidence for the use of external directional clues. Mar Biol 117: $559-566$

Nelson DR, McKibben JN, Strong WR, Lowe CG, Sisneros JA, Schroeder DM, Lavenberg RJ (1997) An acoustic tracking

Editorial responsibility: Otto Kinne (Editor),

Oldendorf/Luhe, Germany of a megamouth shark, Megachasma pelagios: a crepuscular vertical migrator. Environ Biol Fish 49:389-399

Panigada S, Zanardelli M, Simonepietro C, Jahoda M (1999) How deep can baleen whales dive? Mar Ecol Prog Ser 187: 309-311

Parker HW, Boeseman M (1954) The basking shark (Cetorhinus maximus) in winter. Proc Zool Soc Lond 124:185-194

Parker HW, Stott FC (1965) Age, size and vertebral calcification in the basking shark, Cetorhinus maximus (Gunnerus). Zool Meded (Leiden) 40:305-319

Pingree RD, Pugh PR, Holligan PM, Forster GR (1975) Summer phytoplankton blooms and red tides along tidal fronts in the approaches to the English Channel. Nature 258: 672-677

Priede IG (1984) A basking shark (Cetorhinus maximus) tracked by satellite together with simultaneous remotesensing. Fish Res 2:201-216

Sand A (1938) The function of the ampullae of Lorenzini, with some observations on the effect of temperature on sensory systems. Proc R Soc Lond B 125:524-553

Schreer JF, Kovacs KM (1997) Allometry of diving capacity in air-breathing vertebrates. Can J Zool 75:339-358

Sims DW (1999) Threshold foraging behaviour of basking sharks on zooplankton: life on an energetic knife-edge? Proc R Soc Lond B 266:1437-1443

Sims DW (2000) Filter-feeding and cruising swimming speeds of basking sharks compared with optimal models: they filter-feed slower than predicted for their size. J Exp Mar Biol Ecol 249:65-76

Sims DW, Merrett DA (1997) Determination of zooplankton characteristics in the presence of surface feeding basking sharks (Cetorhinus maximus). Mar Ecol Prog Ser 158: 297-302

Sims DW, Quayle VA (1998) Selective foraging behaviour of basking sharks on zooplankton in a small-scale front. Nature 393:460-464

Sims DW, Fox AM, Merrett DA (1997) Basking shark occurrence off south-west England in relation to zooplankton abundance. J Fish Biol 51:436-440

Sund O (1943) Et brugdebarsel. Naturen 67:285-286

Van Deinse AB, Adriani MJ (1953) On the absence of gill rakers in specimens of basking shark, Cetorhinus maximus (Gunner). Zool Meded (Leiden) 31:307-310

Warner AJ, Hays GC (1994) Sampling by the Continuous Plankton Recorder survey. Prog Oceanogr 34:237-256

Weimerskirch H, Doncaster CP, Cuenot-Chaillet F (1994) Pelagic seabirds and the marine environment: foraging patterns of wandering albatrosses in relation to prey availability and distribution. Proc R Soc Lond B 255:91-97

Welch DW, Eveson JP (1999) An assessment of light-based geoposition estimates from archival tags. Can J Fish Aquat Sci 56:1317-1327

Williams R, Conway DVP (1984) Vertical distribution and seasonal and diurnal migration of Calanus helgolandicus in the Celtic Sea. Mar Biol 79:63-73

Submitted: July 1, 2002; Accepted: November 6, 2002

Proofs received from author(s): February 7, 2003 